Review

\title{
Nanotechnology: Advantages and drawbacks in the field of construction and building materials
}

\author{
F. Pacheco-Torgal ${ }^{\mathrm{a}, *}$, Said Jalali ${ }^{\mathrm{b}, 1}$ \\ ${ }^{a}$ University of Minho, C-TAC Research Unit, 4800 Guimarães, Portugal \\ ${ }^{\mathrm{b}}$ University of Minho, Department of Civil Engineering, 4800 Guimarães, Portugal
}

\section{A R T I C L E I N F O}

\section{Article history:}

Received 13 May 2010

Received in revised form 29 June 2010

Accepted 18 July 2010

Available online $\mathrm{xxxx}$

\section{Keywords:}

Nanotechnology

Nanomaterials

Biomimicry

Nanoindentation

Photocatalysis

Nanotoxicity

\begin{abstract}
A B S T R A C T
Nanotechnology seems to hold the key that allows construction and building materials to replicate the features of natural systems improved until perfection during millions of years. This paper reviews current knowledge about nanotechnology and nanomaterials used by the construction industry. It covers the nanoscale analysis of Portland cement hydration products, the use of nanoparticles to increase the strength and durability of cimentitious composites, the photocatalytic capacity of nanomaterials and also nanotoxicity risks.
\end{abstract}

(c) 2010 Elsevier Ltd. All rights reserved.

\section{Contents}

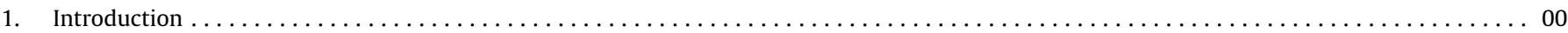

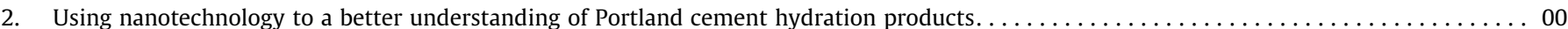

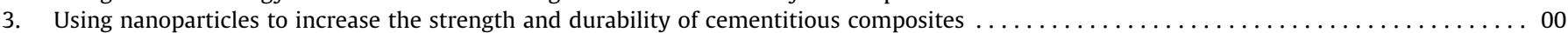

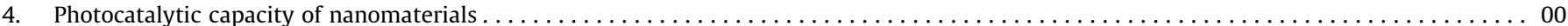

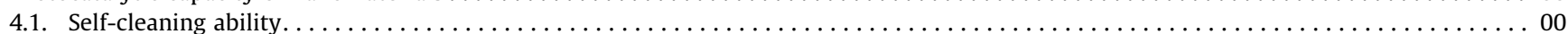

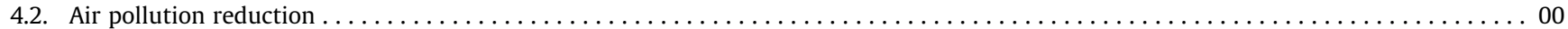

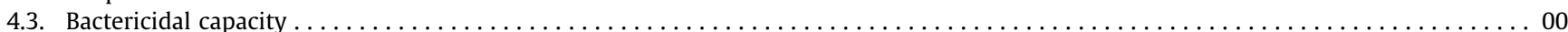

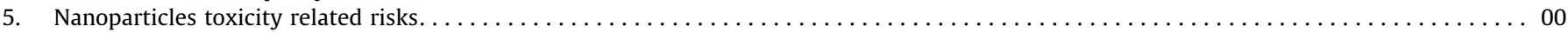

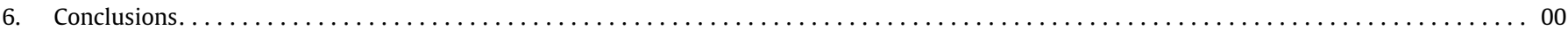

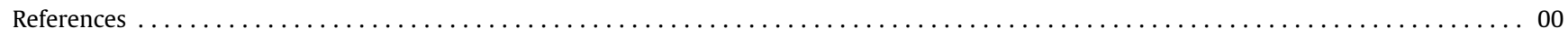

\section{Introduction}

The speech of the physicist Richard Feynmam entitled "There's plenty of room at the bottom" [1], that took place in a Meeting of the American Physical Society in 1959 at CalTech is considered to be the beginning of the nanotechnology era. This last term was nonetheless presented in 1974 by Professor Norio Taguchi, meaning the processing of materials, atom by atom or molecule by molecule [2]. A more accurate definition of nanotechnology was

\footnotetext{
* Corresponding author.

E-mail addresses: torgal@civil.uminho.pt (F. Pacheco-Torgal), said@civil.uminho. pt (S. Jalali).

1 Tel.: +351253 510200; fax: +351253510213
}

presented in 1981 by Drexler [3], such as the production with dimensions and precision between 0,1 and $100 \mathrm{~nm}$. In medium terms nanotechnology involves the study at microscopic scale $\left(1 \mathrm{~nm}=1 \times 10^{-9} \mathrm{~m}\right)$. As a comparison, one must realize that a human hair has $80,000 \mathrm{~nm}$ thickness and that the DNA double helix has $2 \mathrm{~nm}$ diameter. Between 1997 and 2003 the investment in nanotechnology increased at 40\% reaching 35,000 million euro [4]. Some estimates predict that products and services related to nanotechnology could reach 1,000,000 million euro/year beyond 2015 [5]. The report RILEM TC 197-NCM, "Nanotechnology in construction materials" [6], is the first document that synthesis in a clear manner the potential of nanotechnology in terms of the development of construction and building materials, namely:

0950-0618/\$ - see front matter (c) 2010 Elsevier Ltd. All rights reserved. doi:10.1016/j.conbuildmat.2010.07.009 
- The use of nanoparticles, carbon nanotubes and nanofibers to increase the strength and durability of cimentitious composites as well as for pollution reduction.

- Production of cheap corrosion free steel.

- Production of thermal insulation materials with a performance 10 times commercial current options.

- Production of coats and thin films with self-cleansing ability and self color change to minimize energy consumption.

- Production of nanosensores and materials with sensing ability and self-repairing ability.

One of the most promising areas in the field of nanotechnology and also mentioned in the RILEM TC 197-NCM report relates to the replication of natural systems. The continuous improvement of these systems carried out over millions of years leads to materials and "technologies" with exceptional performance and fully biodegradable. For instance, the abalone shells (Fig. 1) are made with $0.2 \mathrm{~mm}$ thickness layers, and each is made by a "mortar" $0.5 \mu \mathrm{m}$ thickness of calcium carbonate crystals bound altogether with a protein. The final result is a composite material with a toughness 3000 times the toughness of the calcium carbonate crystals $[7,8]$.

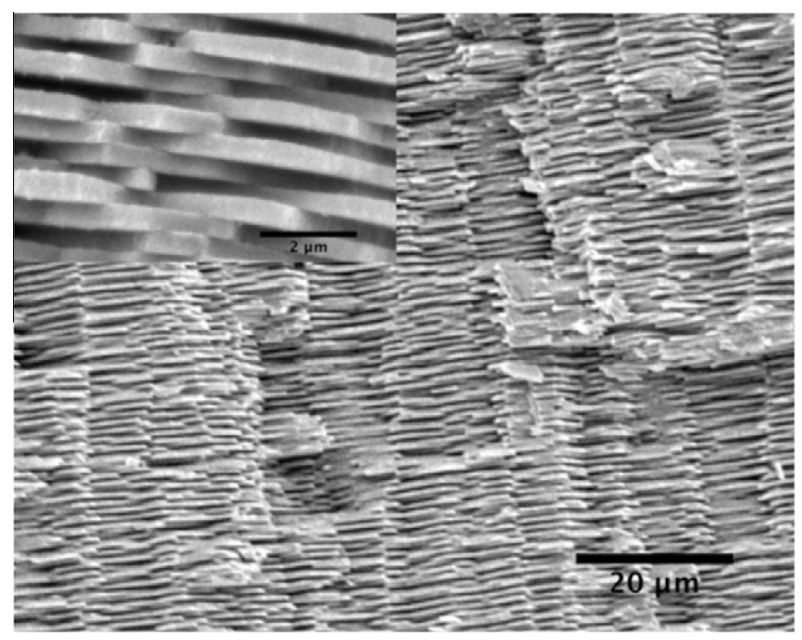

Fig. 1. Microstructure of Haliotis, abalone shell [8].
Another example comes from the spider silk which possesses a strength/mass ratio that exceeds the steel ratio [9-11]. Even comparing the performance of carbon nanotubes (Fig. 2), a high technology product with spider silk, one realizes how natural systems are well optimized. First discovered in Russia in 1952, carbon nanotubes were some years later re-discovered in Japan. These materials possess a tensile strength 100 times over steel but as a downside side they are extremely costly (20-1000 euros/g) [12]. Another biomimicry related finding relates to the coral reef formation. Those natural systems use sea water to produce calcium, magnesium and carbonate to generate a carbonate crystal (aragonite) and recently the enterprise Calera has announced the possibility of producing calcium carbonate using sea water and $\mathrm{CO}_{2}$. Unfortunately the information available is insufficient to take that for granted [13-15]. One high impact application in the field of energy consumption relates to the development of nanomaterials with very high insulation performance, such as aerogel (Fig. 3). This material was developed by NASA in the 1950s and has been known as "solid smoke". It is composed by air (99.8\%) and silica nanoparticles ( $0.2 \%)$ having the lowest thermal conductivity of any solid (between 0.004 and $0.03 \mathrm{~W} / \mathrm{mK}$ ). Recent investigation has tried to produce aerogel based windows [16,17], allowing for future high insulation Windows. The current manuscript reviews the use of nanotechnology in the field of construction and building materials. It covers the nanoscale analysis of Portland cement hydration products, the use of nanoparticles to increase the strength and durability of cimentitious composites, the photocatalytic capacity of nanomaterials, and also nanotoxicity risks.

\section{Using nanotechnology to a better understanding of Portland cement hydration products}

Concrete is the most used construction material on Planet Earth and presents a higher permeability that allows water and other aggressive elements to enter, leading to carbonation and chloride ion attack, resulting in corrosion problems. Therefore, the nanoscale study of the hydration products $(\mathrm{C}-\mathrm{S}-\mathrm{H}$, calcium hydroxide, ettringite, monosulfate, unhydrated particles and air voids), as a form to overcome durability issues, is a crucial step in concrete sustainability. Investigations in this field have already been carried out in recent years [18,19]. Mojumdar and Raki [20] have already analyzed calcium silicate nanophase composites which will allow
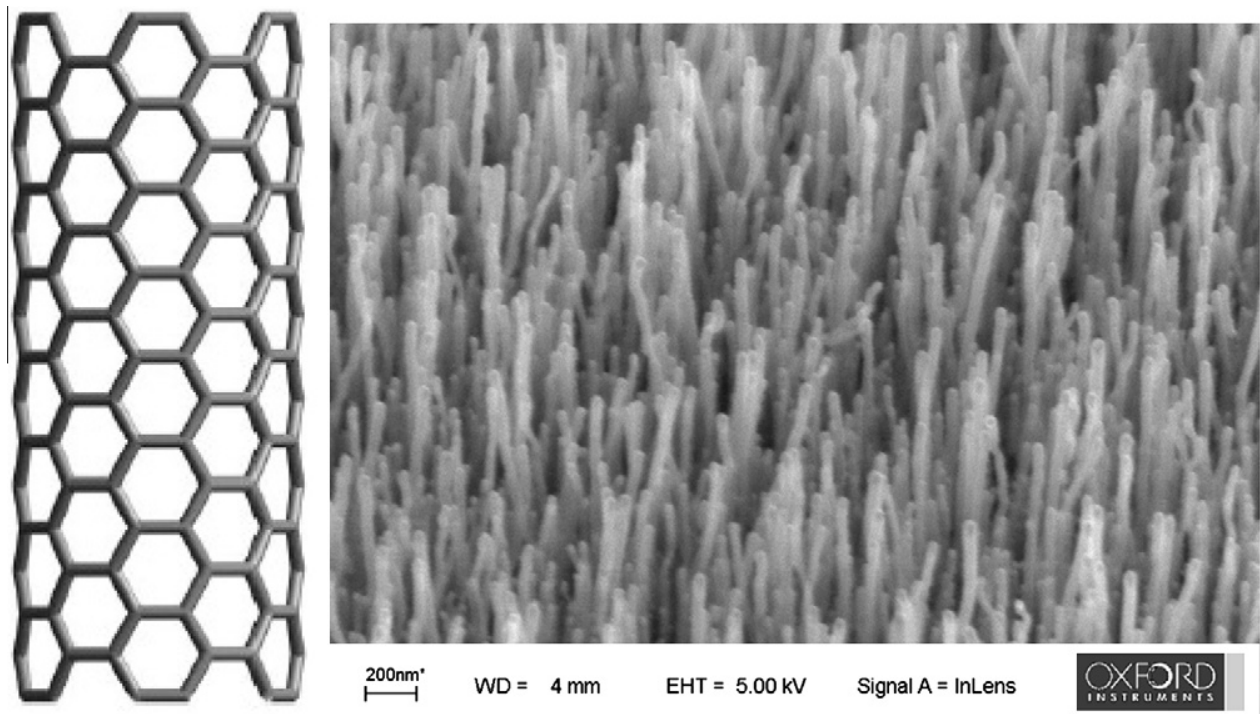

Fig. 2. Carbon nanotubes: right schematics; left microstructure. 


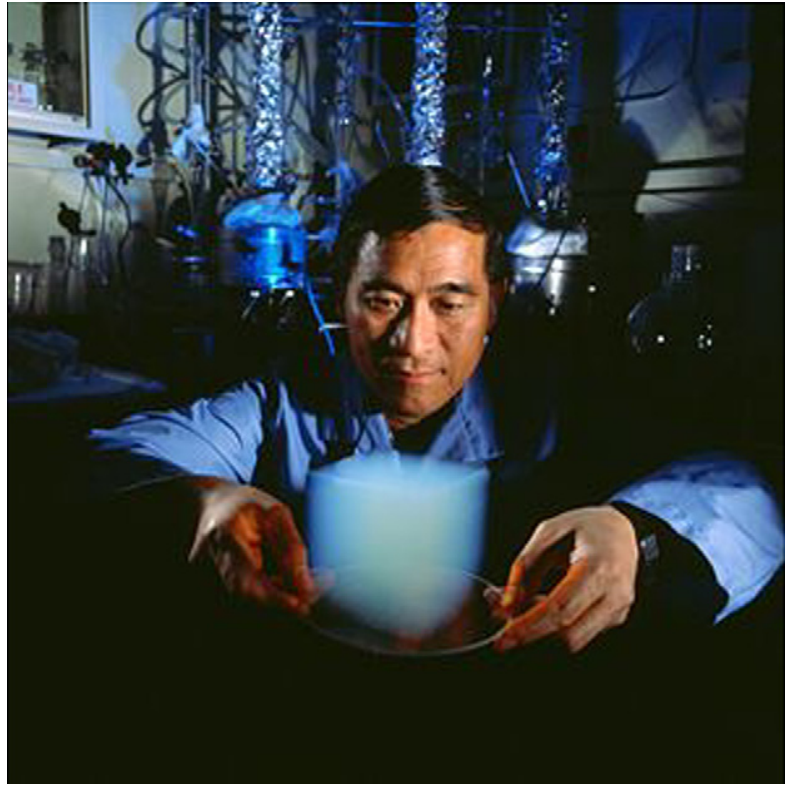

Fig. 3. Aerogel.

the future development of anti-corrosion and fire-retardant coatings. Until very recently electronic microscopy has allowed the understanding of the morphology, as well as the composition of hydration products. However, the use of nanotechnology currently allows the possibility of knowledge of the elastic modulus by nanoindentation techniques (AFM). In nanoindentation a material with known characteristics is used to make a mark in another material with unknown properties and through the specific nature of this mark it is possible to infer the properties of the marked material. Recently Mondal [21] has used nanoindentation in cementitious phases and obtained the following elastic modulus: $35 \mathrm{MPa}$ for the $\mathrm{Ca}(\mathrm{OH})_{2}$ phase; 26 and $16 \mathrm{MPa}$ for high and low stiffness $\mathrm{C}-\mathrm{S}-\mathrm{H}$ and $10 \mathrm{MPa}$ for the porous phase. Even more recently some authors from MIT [22] have used nanotechnology to develop a molecular model for the hydration products of Portland cement (Fig. 4). These authors confirm that the molecular model is in excellent agreement with experimental values obtained by nanoindentation techniques (Fig. 5).

\section{Using nanoparticles to increase the strength and durability of cementitious composites}

Porro et al. [23] mentioned that the use of nanosilica particles increases the compression strength of cement pastes. The same authors state that that phenomenon is not due to the pozzolanic reaction, because calcium hydroxide consumption was very low but, instead, to the increased of silica compounds that contributes to a denser microstructure. According to Lin et al. [24], the use of nanosilica on sludge/fly ash mortars, compensate the negative effects associated to sludge incorporation in terms of setting time and initial strength. Sobolev et al. [25] reported that nanosilica addition led to an increase of strength by $15-20 \%$. Other authors [26] believe that nanosilica leads to an increase of $\mathrm{C}-\mathrm{S}-\mathrm{H}$ chain dimension and also $\mathrm{C}-\mathrm{S}-\mathrm{H}$ stiffness. Chen et al. [27] used nanosilica particles to improve the performance of sludge/clay mixtures for tile production. The results show that nanoparticles improved the reduction of water absorption and led to an increase of abrasion and impact strength. Others [28] also confirm that the use of nanoparticles (nanotubes, nanofibers, nanosilica or nanoclay) is responsible for a higher hydration degree of cementitious com- pounds as long as a higher nanoparticle dispersion can be achieved. Nasibulin et al. [29] reported and increase in strength by 2 times and 40 times for electric conductivity, which means a high potential for sensing ability. Chaipanich et al. [30] mentioned that $1 \%$ of carbon nanofibers (by binder mass) can compensate the strength reduction associated with the replacement of $20 \%$ fly ash. Gdoutos-Konsta et al. [31] also studied the effect of carbon nanofibers on cement pastes $(0.08 \%$ by binder mass) observing an increase in strength. Those authors used ultra-sounds to achieve a high nanofiber dispersion stating that that is a crucial step in order to obtain a high performance of nanotubes in the cement matrixes. Nevertheless, the fact that carbon nanotubes are not cost-efficient prevents the increase in commercial applications in a near future.

\section{Photocatalytic capacity of nanomaterials}

The most known application of nanomaterials in the construction industry relates to the photocatalytic capacity of semiconductor materials. Several semiconductors materials, such as $\mathrm{TiO}_{2}, \mathrm{ZnO}$, $\mathrm{Fe}_{2} \mathrm{O}_{3}, \mathrm{WO}_{3}$ and $\mathrm{CdSe}$, possess photocatalytic capacity [32]. However, $\mathrm{TiO}_{2}$ is the most used of all because of its low toxicity and stability [33]. Titanium dioxide can crystallize as rutile, anatase and brookite, being the first form the most stable (thermodynamically speaking), it is also the most available form (it is the 9th most abundant element in the Earth crust) and is currently used as additive in the painting industry. The anatase and brookite forms are meta-stable and can be transformed into rutile by thermal treatment. Being a semiconductor with photocatalytic capacity, when $\mathrm{TiO}_{2}$ is submitted to UV rays $(320-400 \mathrm{~nm})$, in the presence of water molecules, it leads to the formation of hydroxyl radicals $(\mathrm{OH})$ and superoxide ions (O2-). Those highly oxidative compounds react with dirt and inorganic substances promoting their disintegration. Photocatalysis of $\mathrm{TiO}_{2}$ is also responsible for the reduction of the contact angle between water droplets and a given surface, leading to super-hydrophobic or super-hydrophilic surfaces increasing their self-cleansing capacity. Water repellent surfaces are one of the features of natural systems as it happens in the leaves of the lotus plant (Fig. 6), whose microstructure allows self-cleansing ability [34,35]. According to Fujishima et al. [36], the potential of photocatalysis can be perceived by the number of citations of a related paper published on Nature in 1972, as well as by the number o papers concerning photocatalysis investigations that increased in an exponential pattern between 1997 and 2007 (Fig. 7). Another form to evaluate the potential of this technology is by knowing that the Japanese Corporation TOTO Ltd has already issued 1200 international patent requests in this field. So far 500 have been approved. The applications related photocatalysis cover five groups: self-cleaning, air-cleaning, anti-bacterial, anti-fogging and water treatment. Considering the cost to clean graffiti (in Los Angeles city this could amount to 100 million euro/year [37]) one can realize the huge potential of the photocatalytic capacity of nanomaterials.

\subsection{Self-cleaning ability}

Although self-cleaning properties of catalysts materials are known since the 1960s [38], only recently they start to be used in a wide manner. The first application of self-cleaning concrete took place in the church "Dives in Misericordia" in Rome (Fig. 8). This building was designed by the Arq ${ }^{\circ}$ Richard Meyer and officially opens in 2003. It is composed by 346 prestressed concrete blocks made with white cement and $\mathrm{TiO}_{2}$ (binder $380 \mathrm{~kg} / \mathrm{m}^{3}$ and $\mathrm{W} / \mathrm{B}=0.38$ ) [39]. Visual observations carried out 6 years after construction revealed only slightly differences between the white color of the outside concrete surfaces and the inside blocks [40]. 


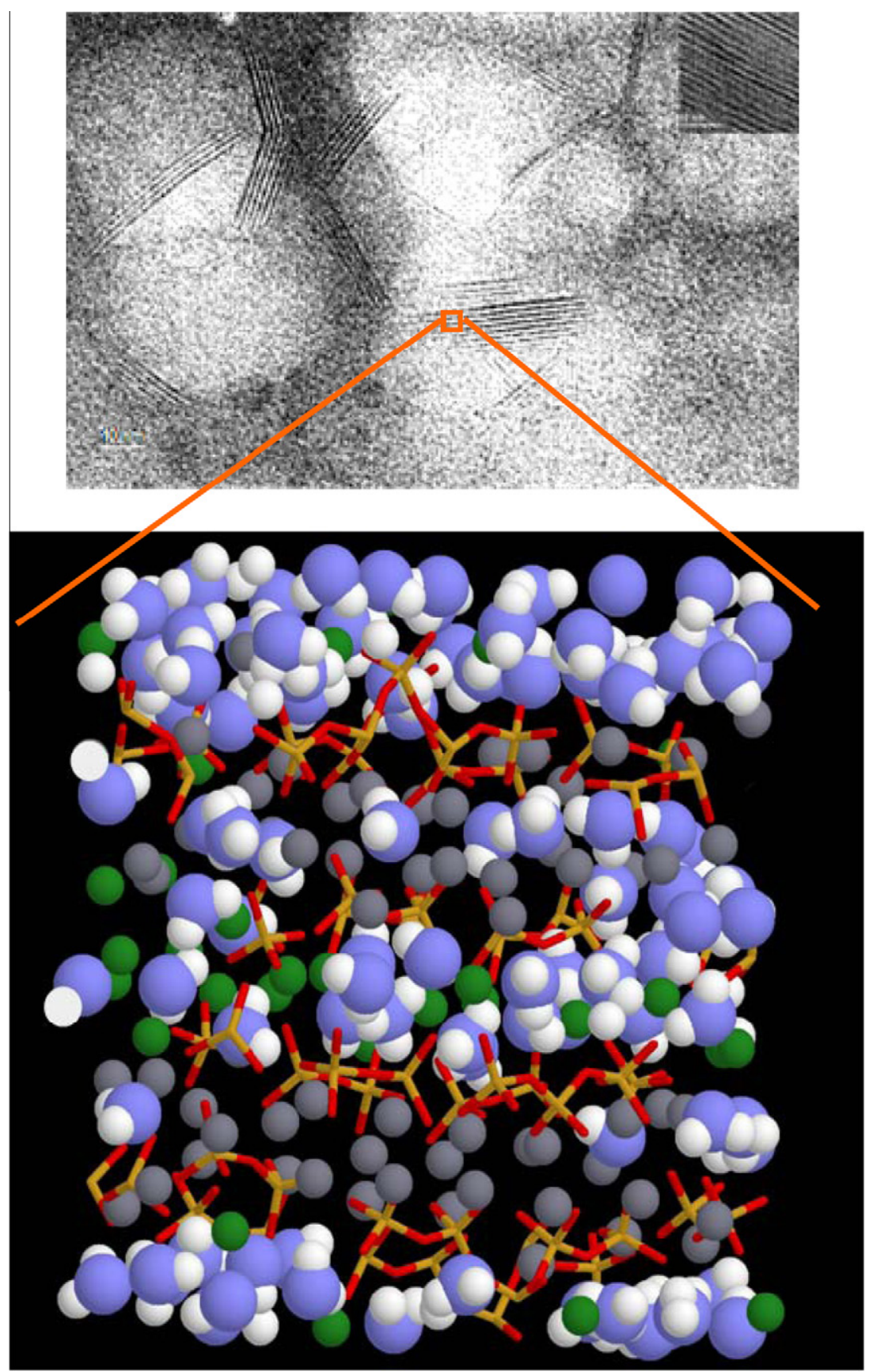

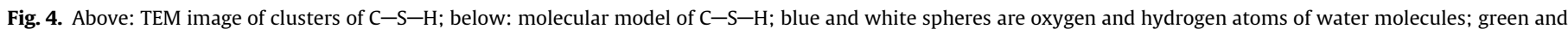

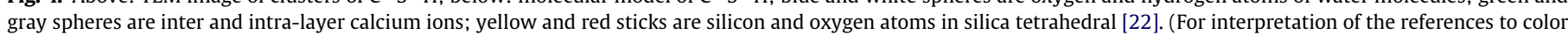
in this figure legend, the reader is referred to the web version of this article.)

Diamanti et al. [41] study mortars containing $\mathrm{TiO}_{2}$ having noticing reductions in the contact angle between water and solid surface of almost $80 \%$. Ruot et al. [42] mentioned that photocatalytic activity is dependent on the matrix properties. Increasing $\mathrm{TiO}_{2}$ content in cement pastes above $1 \%$ leads to a proportional increase in photocatalytic activity, as for mortars a $\mathrm{TiO}_{2}$ content increase just lead to a very small increase in the photocatalytic activity. Those authors suggest that most $\mathrm{TiO}_{2}$ particles in mortars are not reached by UV radiation.

\subsection{Air pollution reduction}

Zhao \& Yang [43] mentioned a high photocatalytic capacity for indoor air pollution reduction when using $\mathrm{P} 25 \mathrm{TiO}_{2}$ (70\% ana- tase $+30 \%$ rutile) with $300 \mathrm{~nm}$ diameter and a specific surface of $50 \mathrm{~m}^{2} / \mathrm{g}$. Yu et al. [44] study cementitious paving blocks for NOx reduction, noticing that the photocatalytic capacity is reduced by the presence of dust, grease or plastic gum, thus suggesting that these blocks should not be placed in pedestrian areas. Maier et al. [45] reported a fast pollution reduction in indoor air by the use of gypsum plasters containing $10 \% \mathrm{TiO}_{2}$ (Fig. 9).Those authors mentioned that although air pollution reduction is dependent on the UV intensity, nevertheless, visible light still allows acceptable degradation rates. Those plasters were used to cover some bedrooms in Sweden, being responsible for a reduction on VOC of about $1 / 3$ (to $26 \mu \mathrm{g} / \mathrm{m}^{3}$ ). Strini et al. [46] mentioned that $\mathrm{TiO}_{2}$ thin films possess a photocatalytic capacity which is 3-10 times higher than for $\mathrm{TiO}_{2}$ cementitious composites. In 2006 the results of the 


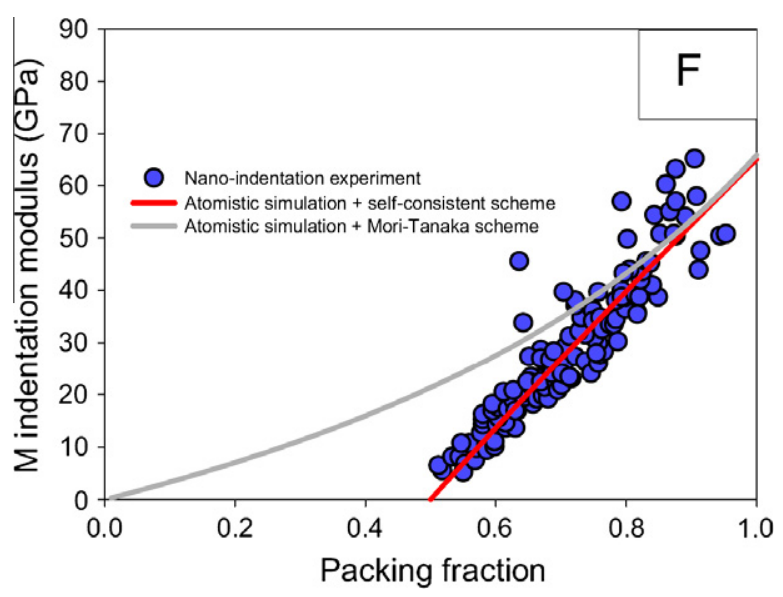

Fig. 5. Nanoindentation data [22].

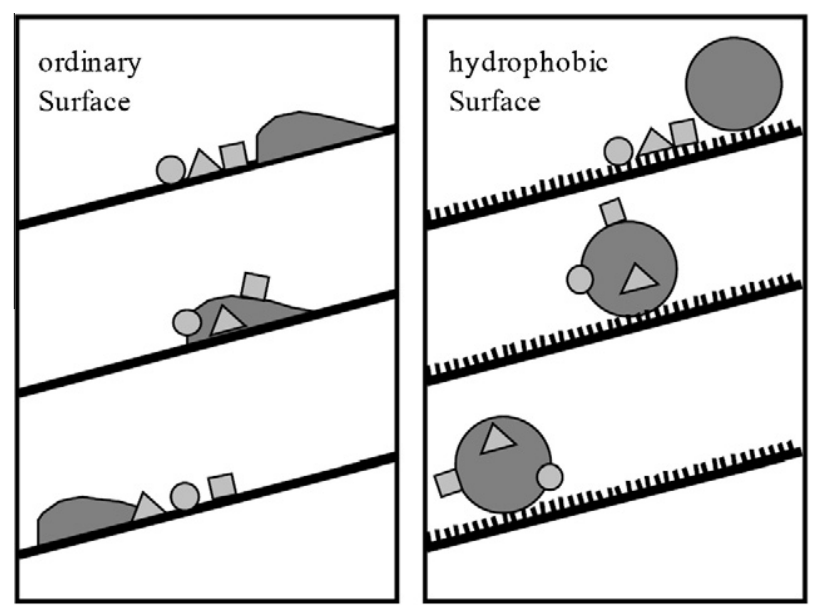

Fig. 6. Lotus effect [34].

PICADA project "Photo-catalytic innovative coverings applications for de-pollution assessment" [47] aiming to the development of $\mathrm{TiO}_{2}$ based coatings for self-cleaning and air pollution reduction coatings were disclosed. Aside from the study of small specimens in laboratory the PICADA project also covered pilot tests at macro-scale $(1: 5)$ in order to reply the effect of a street by using $\left(18 \times 5.18 \mathrm{~m}^{2}\right)$ "walls" and an artificial NOx pollution source. The results showed a reduction in NOx emissions between $40 \%$ and $80 \%$. However, results published in a scientific journal mentioned NOx reductions between $36.7 \%$ and $42 \%$ [48]. The use of a threedimensional numerical model (MIMO) based on the data generated in the pilot test allows the insertion of win velocity and temperature in order to predict the reductions in air pollution by the photocatalytic activity of the facade coatings. In another macro-scale test carried out in the PICADA project, the ceiling of an underground car park $\left(322 \mathrm{~m}^{2}\right)$ was painted with $\mathrm{TiO}_{2}$ based paint. Then the park was sealed and polluted by the exhaust gas from a single car. The results showed a reduction on NOx due to the photocatalytic capacity of the paint in the ceiling. Wang et al. [49] confirmed that in the last few years a lot of research has been made about the reduction of indoor air pollution when using UV radiation but very few have analyzed the possibility of using phocatalysts active under visible light. Poon and Cheung [50] mentioned that $\mathrm{TiO}_{2}$ cementitious composites with increased porosity have high NOx reduction (Fig. 10). Those authors compared the performance of several $\mathrm{TiO}_{2}$ forms, concluding that although P25 is much more
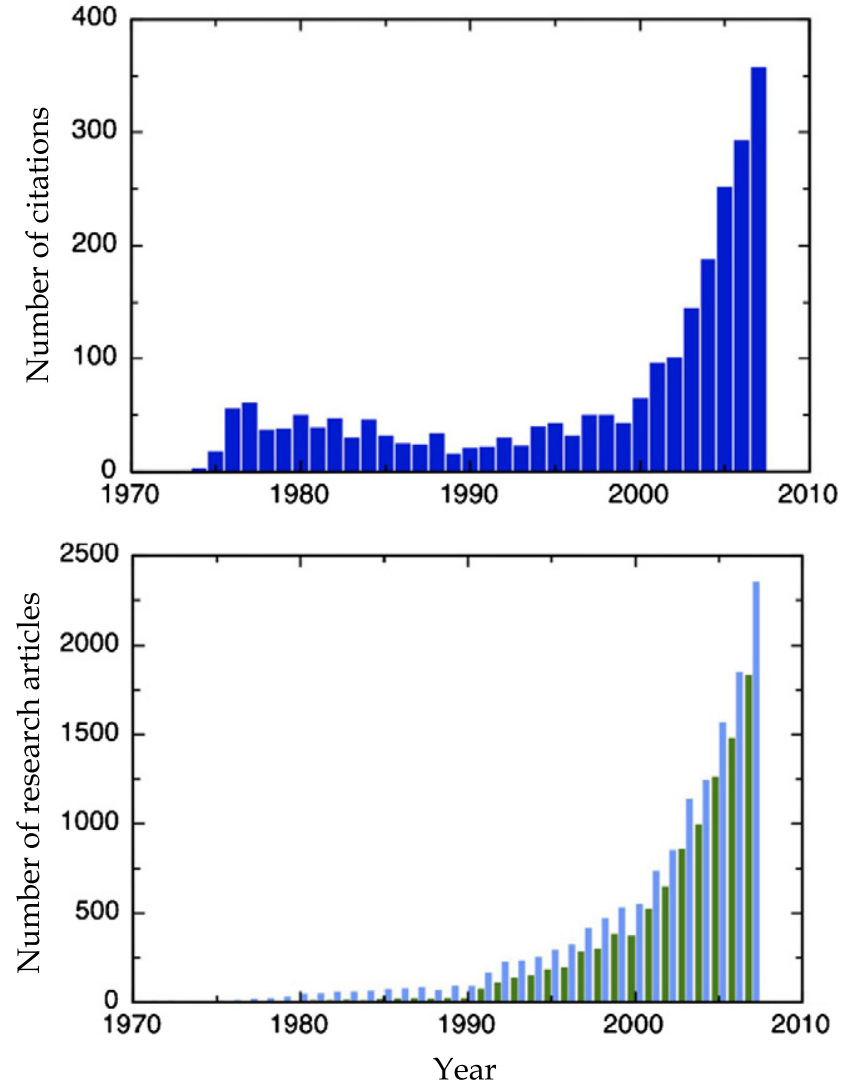

Fig. 7. Above: citations of the 1972 Nature paper "Electrochemical photolysis of water at a semi conductor electrode"; below number of research articles published in the "Web of Science" between 1972 and 2007, blue bars - by the keyword "photocataly", green bars - by the keywords " $\mathrm{TiO}_{2}$ and photocataly" [36]. (For interpretation of the references to color in this figure legend, the reader is referred to the web version of this article.)

reactive (Fig. 11) it has not a very high performance/cost ratio. Guerrini and Peccati [51] mentioned a case of a street in Bergamo, Italy, paved with blocks $\left(12.000 \mathrm{~m}^{2}\right)$ of photocatalytic properties where high reductions of NOx (45\%) have been reported [52]. In Tokyo cement mixtures containing $\mathrm{TiO}_{2}$ colloidal solutions were used to coated several road areas (Fig. 12). The results obtained in an area of $300 \mathrm{~m}^{2}$ show $50-60 \mathrm{mg} /$ day NO degradation [36]. Auvinen et al. [53] studied the reduction of VOC in indoor air when using paints with $\mathrm{TiO}_{2}$ applied in several substrates (glass, gypsum, polymer) noticing that the substrate does not influences the photocatalytic reaction. Those authors mentioned that organic additives must not be used for this paints because they will be damaged by the radical hydroxyls. Also that the photocatalytic reactions generates more than just water and $\mathrm{CO}_{2}$ but also other pollutants that are harmful for human health. Other authors [54] confirm reductions of NOx between $23 \%$ and $63 \%$ when using $\mathrm{TiO}_{2}$ based tiles. They also reported that the accumulation of reaction products generated in the oxidation process reduces the photocatalytic activity. For the production of $\mathrm{TiO}_{2}$ based cementitious composites some authors [55] recommend the use of $\mathrm{TiO}_{2}$ as a solution with the mixing water because it allows for a better dispersion than if it is mixed with the cement. Also that a semiconductor with high specific surface gives a better result than the use of a superior volume of low specific surface semiconductor. These authors used a specific surface $\mathrm{TiO}_{2}$ (between 0.7 and $1.5 \mathrm{~m}^{2} / \mathrm{g}$ ) which is much lower than the P25 form. They also confirmed the results of others [50] about the high photocatalytic capacity when high porosity mortars are used. Chen and Poon [56] found out that when using grounded glass for partial sand replacement the photocatalytic capacity can 


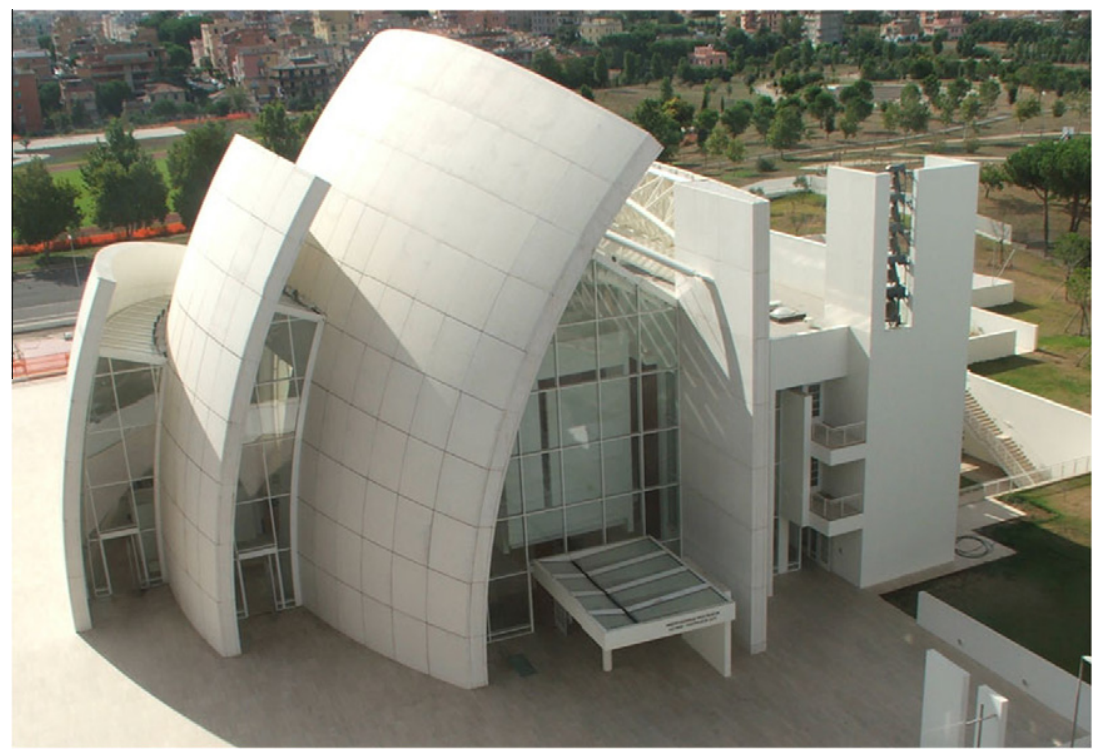

Fig. 8. Church “Dives in Misericordia”, Rome, Italy.

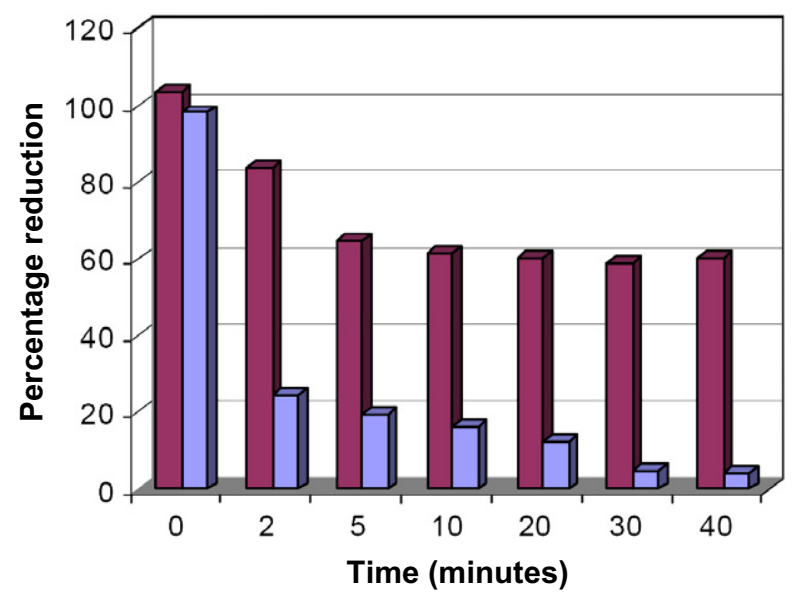

Fig. 9. Degradation of formaldehyde in gypsum plasters: blue-plaster with catalyst; purple-plaster without catalyst [45]. (For interpretation of the references to color in this figure legend, the reader is referred to the web version of this article.)

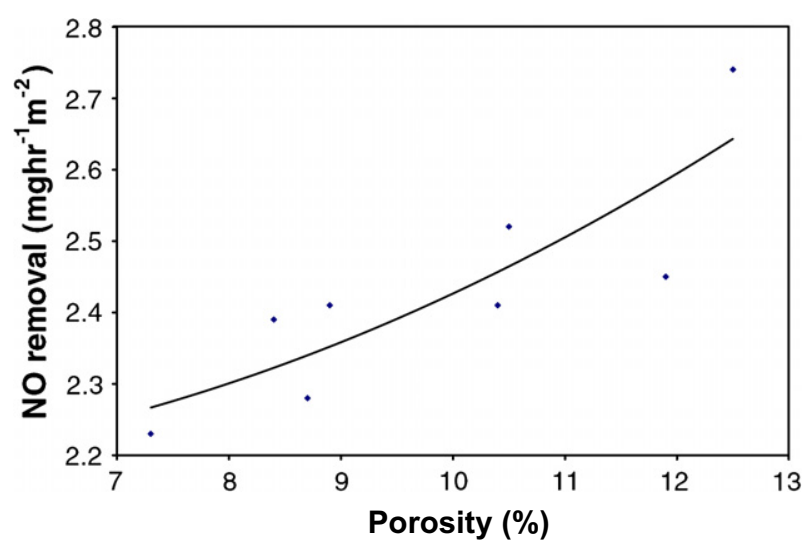

Fig. 10. Influence of porosity mixes and NO removal [50].

be 3 times higher for lighter glasses. Those authors suggest that glass particles can allow light to enter more deeply in the mortar leading to a higher oxidation. Kolarik et al. [57] confirm that the photocatalytic reaction is a good way to reduce VOC in indoor air. Ramirez et al. [58] mentioned that substrate porosity influences photocatalyty reaction when $\mathrm{TiO}_{2}$ thin films are used being that a high porosity surface leads to a high reaction. Ballari et al. [59] presented a model that can predict NOx reduction using concrete with $\mathrm{TiO}_{2}$ particles. Hassan et al. [60] used $41 \mathrm{MPa}$ concrete blocks covered with $1 \mathrm{~cm} \mathrm{TiO} 2$ based mortar layer in order to evaluate nanoparticles removal by abrasion tests and thus reducing the photocatalytic capacity in NOx reduction. Those authors mentioned that even after 20.000 abrasion cycles the NOx degradation reduction remained stable.

\subsection{Bactericidal capacity}

One of the most important applications of materials with photocatalytical properties concerns the destruction of fungi and bacteria. Indoor fungi and bacteria proliferation are one of the main causes responsible for construction materials degradation and also for health problems [61-64], because fungi are responsible for mycotoxins growth [65]. Saito et al. [66] study the addition of $\mathrm{TiO}_{2}$ powder with an average size $21 \mathrm{~nm}$ (30\% rutile and $70 \%$ anatase) to a bacterial colony. The results show that 60-120 min were sufficient to destroy all the bacteria. Those authors state that using bigger $\mathrm{TiO}_{2}$ particles reduces the bactericidal capacity and that the best results are obtained for a $\mathrm{TiO}_{2}$ concentration of 0.01 and $10 \mathrm{mg} / \mathrm{ml}$. Huang et al. [67] also confirm that using lower dimension $\mathrm{TiO}_{2}$ particles leads to a faster bacterial destruction. Those authors notice that bacteria destruction begins after $20 \mathrm{~min}$ of UV radiation exposition, being that after $60 \mathrm{~min}$ all of them have been destroyed. They also reported that after the destruction has been initiated the fact that UV radiation is stopped does not reduce the bactericidal effect. Some authors [68] believe that the bactericidal capacity associated with $\mathrm{TiO}_{2}$ photocatalysis is dependent on the use of UV-A radiation with a wavelength between 320 and $400 \mathrm{~nm}$, being that UV-C type is only effective if the light is applied in a direct manner, thus preventing the treatment of less illuminated areas. Cho et al. [69] confirm that hydroxyl radicals are the main responsible for the bactericidal capacity of semiconductors photocatalysts. Those authors mentioned that hydroxyl radicals possess a destruction capacity of Escherichia Coli bacteria which is $1000-10,000$ more effective than chemical disinfection products. 


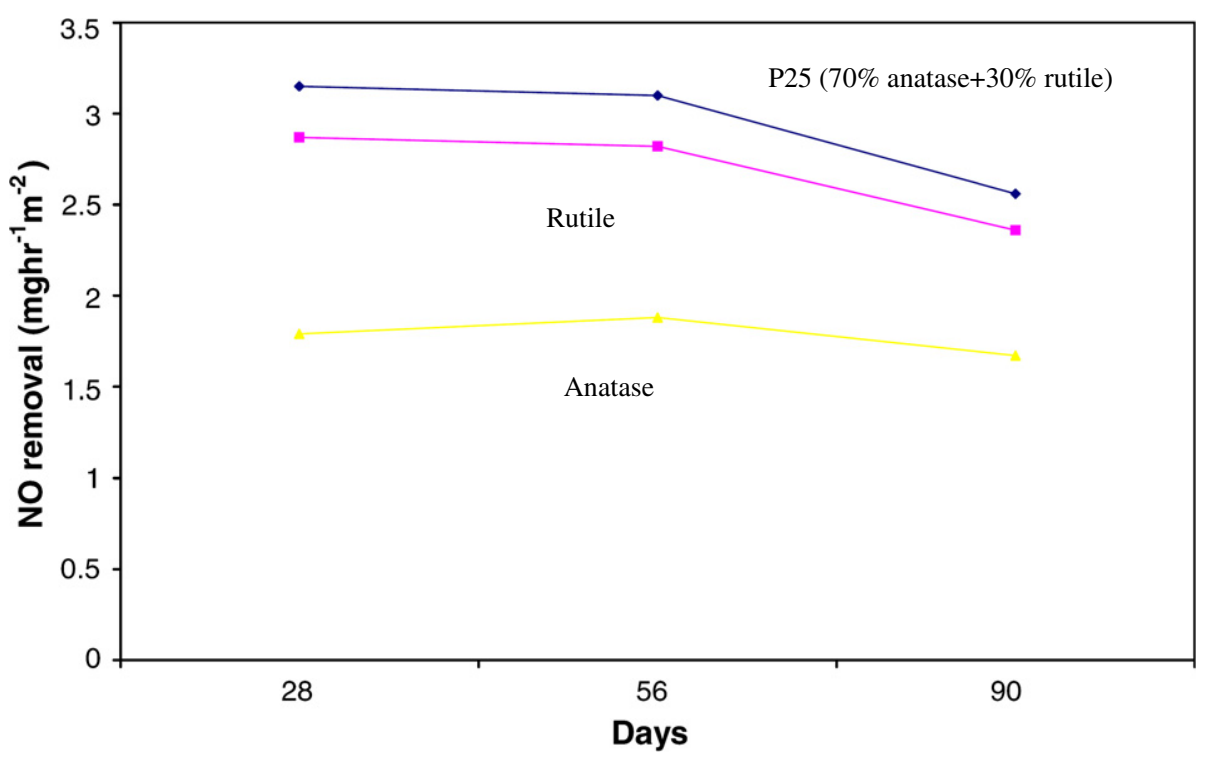

Fig. 11. NO removal for specimens containing different sources of $\mathrm{TiO}_{2}$ [50].
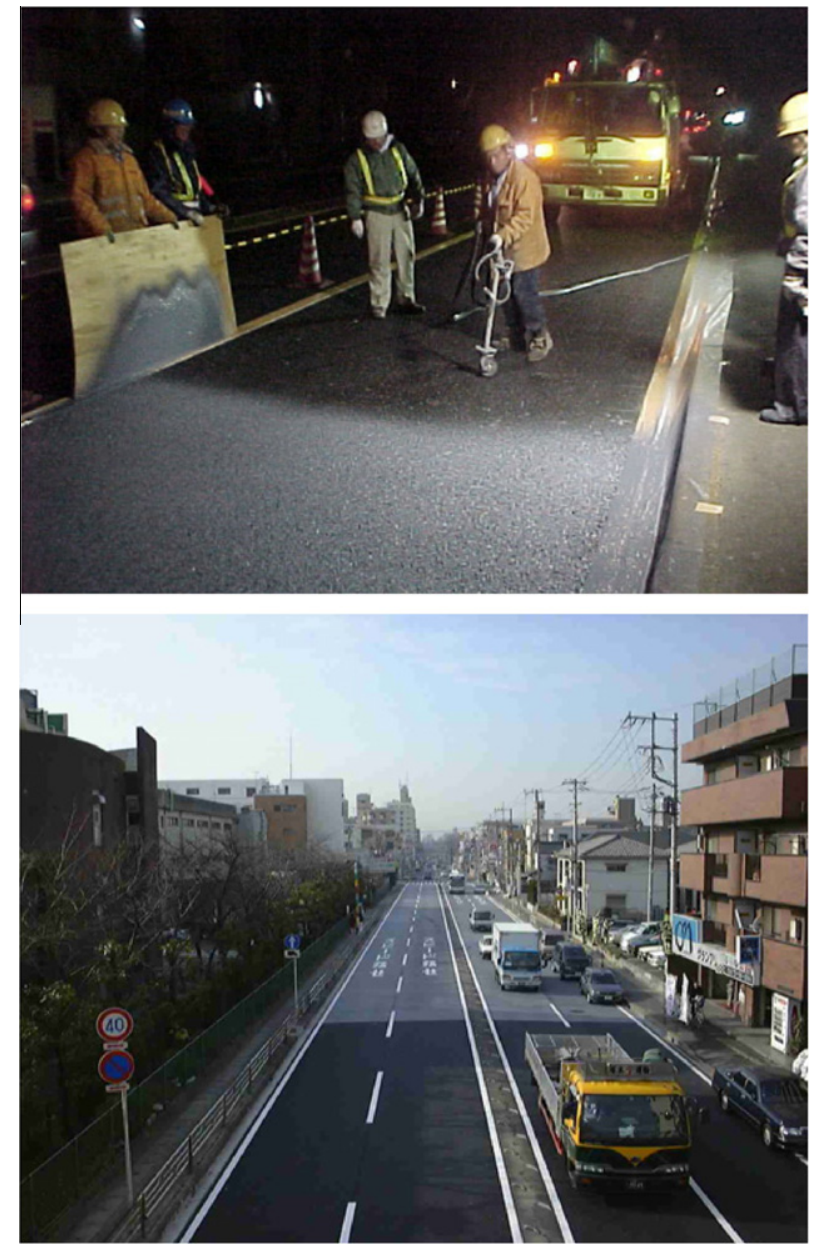

Fig. 12. Using $\mathrm{TiO}_{2}$ photocatalytic material on roadway for pollution reduction: left - coating application; right - finished road showing a lighter color [36].

Vhora et al. [70] used silver doped $\mathrm{TiO}_{2}$ noticing $100 \%$ bacteria destruction just after 2 min which compares in a most favorable manner with current $\mathrm{TiO}_{2}$ which took $2 \mathrm{~h}$ to achieve the same destruction level. Others [71] used wood specimens coated with $\mathrm{a} \mathrm{TiO}_{2}$ thin film $\left(1.5 \mathrm{mg} / \mathrm{cm}^{2}\right)$ noticing that the photocatalytic reaction prevented fungi growth. Calabria et al. [72] analyzed the application of $\mathrm{TiO}_{2}$ thin films (20-50 nm thickness) by the sol-gel process in adobe blocks as a way to increase their water absorption and the bactericidal capacity. Those authors mentioned that $\mathrm{TiO}_{2}$ thin films could be more cost-effective than current commercial paints. One of the main disadvantages of the bactericidal effect associated with photocatalysis relates to the need of UV radiation with a wavelength between $200 \mathrm{~nm}$ and $400 \mathrm{~nm}$, however, recent findings show some possibilities in the development of composite materials with photocatalytic properties even when exposed to visible light $[73,74]$.The use of titanium and trioxide tungsten based films showed high photocatalytic capacity under visible light above $400 \mathrm{~nm}$ [75,76]. Herrmann et al. [77] mentioned several questions that should be addressed in a near future:

- Used of semiconductors not $\mathrm{TiO}_{2}$ based.

- Fotocatalysis activation using visible light.

- Development of semiconductors with improved bactericidal capacity.

\section{Nanoparticles toxicity related risks}

Although the use of nanoparticles is very recent, it has already raised issues concerning its potential toxicity. Some investigations showed that nanoparticles can cause symptoms like the ones caused by asbestos fibers. Grassian et al. [78] studied the effects related to the inhalation of $\mathrm{TiO}_{2}$ particles with a primary particle size between 2 and $5 \mathrm{~nm}$, reporting lung inflammation for a concentration of $8.8 \mathrm{mg} / \mathrm{m}^{3}$. These symptoms have been confirmed by other authors [44,79-82]. Hallock et al. [83] recommend that the use of nanoparticles should be made with the same care already used in Universities for materials of unknown toxicity, i.e., by using air extraction devices to prevent inhalation and gloves to prevent dermal contact. Singh et al. [84] mentioned the possibility of DNA damage resulting in later cancer development. Some authors [85] believe that the nanotoxicity risk depends on the nanoparticles type, concentration volume superficial characteristics. Others [86] suggest that several categories and new parameters must be formulated to better analyze this subject. Some questions that deserve further investigation are presented elsewhere $[87,88]$. Bystrzejewska-Piotrowska et al. [89] have recently carried out an 
extended literature review on this subject. These authors mentioned that Environment Protection Agency has considered that carbon nanotubes are a new form of carbon that must be treated under the toxic products Act. These authors also mentioned that nanoparticles may be responsible for a new kind of problem, the appearance of nanowastes. They suggest that products containing nanoparticles should be labeled in order to facilitate future separation and recycling procedures.

\section{Conclusions}

Nanotechnology has the potential to be the key to a brand new world in the field of construction and building materials. Although replication of natural systems is one of the most promising areas of this technology, scientists are still trying to grasp their astonishing complexities. Nanoscale analysis of Portland cement hydration products will allow more durable binders but the question related to when that will happen is not clear. The fact that nanoparticles are not cost-efficient prevents their commercial applications in a near future. Photocatalytic applications of nanomaterials are already a reality, still more research efforts are needed in order to find other semiconductors apart from $\mathrm{TiO}_{2}$ and conductors that can be activated with visible light. Further research is also needed in the field of nanotoxicity, be there as it may, extreme caution must be used when using nanoparticles.

\section{References}

[1] Feynman R. Therés plenty of room at the bottom (reprint from the speech given at the annual meeting of the West Coast section of the American Physical Society. Eng Sci 1960;23:22-36.

[2] Taniguchi N. On the basic concept of Nano-technology. In: Proceedings of International Conference on Production Engineering Tokyo, Part II, vol. 2. Japan Society of Precision Engineering; 1974. p. 18-23.

[3] Drexler K. Molecular engineering: an approach to the development of general capabilities for molecular manipulation. Proc Natl Acad Sci USA $1981 ; 78: 5275-8$

[4] Andersen M, Molin M. NanoByg- a survey of nanoinnovation in Danish construction. Risoe National Laboratory, Technical University of Denmark; 2007. ISBN 978-87-550-3589-8.

[5] NSF. Societal implications of nanoscience and nanotechnology, USA; 2001

[6] Zhu W, Bartos P, Porro A. Application of nanotechnology in construction. Summary of a state-of-the-art report. RILEM TC 197-NCM. Mater Struct 2004;37:649-58

[7] Li X, Chang W, Chao Y, Wang R, Chang M. Nanoscale structural and mechanical characterization of a natural of a natural nanocomposite material: the shell of red abalone. Nano Lett 2004:4:613-7.

[8] Meyers M, Lim C, Nizam B, Tan E, Seki Y, McKittrick J. The role of organic intertile layer in abalone nacre. Mater Sci Eng 2009;C29:2398-410.

[9] Porter D, Vollrath F. Nanoscale toughness of spider silk. Nanotoday 2007;2:3.

[10] Lee S, Pippel E, Gosele U, Dresbach C, Qin Y, Chandran C, et al. Greatly increased toughness of infiltrated spider silk. Science 2009;324:488-92.

[11] Harrington M, Masic A, Holten-Andersen N. Iron-clad fibers: a metal-based biological strategy for hard flexible coatings. Science 2010:216-20.

[12] Man S. Nanotechnology and construction. Nanoforum report, Institute of Nanotechnology; 2006.

[13] Mitchell S. Capturing carbon. Concr Producer 2009;27:98.

[14] Mitchell S. Capturing carbon. Concr Constr-World Concr 2009;54:104

[15] Geyer R, Del Maestro C, Rohloff A. Greenhouse gas footprint análisis of the Calera process. California: University of California; 2009.

[16] Wittwer V. Development of aerogel windows. J Non-Cryst Solids 1992;145: 233-6.

[17] Venkateswara R, Pajonk G, Haranath D. Synthesis of hydrophobic aerogels for transparent window insulation applications. Mater Sci Technol 2001;17: 343-8

[18] Porro A, Dolado J. Overview of concrete modeling. In: Proceedings of the international conference on applications of nanotechnology in concrete design; 2005. p. 35-45.

[19] Balaguru P, Chong K. Nanotechnology and concrete: research opportunities. ACI FALL 2006 convention, nanotechnology of concrete: recent developments and future perspectives, Code 76,031;2006.

[20] Mojumdar S, Raki L. Synthesis, thermal and structural characterization of nanocomposites for potential applications in construction. J Therm Anal Calorim 2006;86:651-7.

[21] Mondal P. Nanomechanical properties of cementitious materials. PhD Thesis in civil and environment engineering. Northwestern University, Illinois, USA; 2008.
[22] Pellenq R, Kushima A, Shahsavar R, Vliet K, Buehler M, Yip S, et al. editor. A realistic molecular model of cement hydrates. Northwestern University, PNAS; 2009.

[23] Porro A, Dolado J, Campillo I, Erkizia E, De Miguel Y, De Ybarra Y et al. Effects of nanosilica additions on cement pastes. In: Proceedings of the internationa conference on applications of nanotechnology in concrete design; 2005. p. 87 96.

[24] Lin D, Lin K, Chang W, Luo H, Cai M. Improvements of nano-SiO $\mathrm{S}_{2}$ on sludge/fly ash mortar. Waste Manage 2008;28:1081-7.

[25] Sobolev K, Flores I, Hermosillo R, Torres-Martinez L. Nanomaterials and nanotechnology for high-performance cement composites, vol. 254. American Concrete Institute: ACI Special Publication; 2008. p. 93-120.

[26] Gaitero J. Multi-scale study of the fibre matrix interface and calcium leaching in high performance concrete. PhD Thesis, Centre for nanomaterials applications in construction of Labein-Tecnalia, Spain; 2008.

[27] Chen L, Lin D. Applications of sewage sludge ash and nano-SiO2 to manufacture tile as construction material. Constr Build Mater 2009;23: 3312-20.

28] Vera-Agullo J, Chozas-Ligero V, Portillo-Rico D, Garcia-Casas M, GutierrezMartinez A, Mieres-Royo J, et al. Mortar and concrete reinforced with nanomaterials. Nanotechnology in Construction 3, Germany: Springer Berlin Heidelberg; 2009. ISBN 978-3-6-42-00,979-2.

[29] Nasibulin A, Shandakov S, Nasibulina L, Cwirzen A, Mudimela P, HabermehlCwirzen K, et al. New J Phys 2009;11:023013.

[30] Chaipanich A, Nochaya T, Wongkeo W, Torkittikul P. Compressive strength and microstructure of carbon nanotubes-fly ash cement composites. Mater Sci Eng 2010;A527:1063-76

[31] Gdoutos-Konsta M, Metaxa Z, Shah S. Highly dispersed carbon nanotube reinforced cement based materials. Cem Concr Res 2010;40:1052-9.

[32] Makowski A, Wardas W. Photocatalytic degradation of toxins secreted to water by cyanobacteria and unicellular algae and photocatalytic degradation of the cells of selected microorganisms. Curr Top Biophys 2001;25:19-25.

[33] Djebbar K, Sehili T. Kinetics of heterogeneous photocatalytic decomposition of 2,4-dichlorophenoxyacetic acid over $\mathrm{TiO} 2$ and $\mathrm{ZnO}$ in aqueous solution. Pestic Sci 1998;54:269-76.

[34] Benedix R, Dehn F, Quaas J, Orgass M. Application of titanium dioxide photocatalysis to create self-cleaning building materials. Lacer 2000;5: 158-68.

[35] Koch K, Barthlott W. Superhydrophobic and superhydrophilic surfaces: an inspiration for biomimetic materials. Philos Trans Royal Soc A: Math Phys Eng Sci 2009;367:1487-509.

[36] Fujishima A, Zhang $\mathrm{X}$, Tryk $\mathrm{D}$. $\mathrm{TiO}_{2}$ photocatalyst and related surface phenomena. Surf Sci Rep 2008;63:515-82.

[37] Castano V, Rodriguez R. A nanotechnology approach to high performance antigraffiti coatings. In: Presentation at the nanotechnology in crime prevention conference, London, England, 2003.

[38] Fujishima A, Honda K. Electrochemical photolysis of water at a semiconductor electrode. Nature 1972;238:37-8.

[39] Cassar L, Pepe C, Tognon G, Guerrini G, Amadelli R. White cement for architectural concrete, possessing photocatalytic properties. In: 11th International congress on the chemistry of cement, Durban; 2003.

[40] Chen J, Poon C. Photocatalytic construction and building materials: from fundamentals to applications. Build Environ 2009;44:1899-906.

[41] Diamanti M, Ormellese M, Pedeferri M. Characterization of photocatalytic and superhydrophilic properties of mortars containing titanium dioxide. Cem Concr Res 2008;38:1343-53.

42] Ruot B, Plassais A, Olive F, Guillot $\mathrm{L}$, Bonafous $\mathrm{L}_{\text {. }} \mathrm{TiO}_{2}$-containing cement pastes and mortars: measurements of the photocatalytic efficiency using rhodamine B-based colorimetric test. Sol Eng 2009;83:1794-801.

[43] Zhao J, Yang X. Photocatalytic oxidation for indoor air purification: a literature review. Build Environ 2003;38:645-54.

[44] Yu Y, Zhang Q, Mu Q Zhang B, Yan B. Exploring the immunotoxicity of carbon nanotubes. Nanoscale Res Lett 2008;3:271-7.

[45] Maier W, Nilsson C, Holzer M, Lind J, Rosebom, K. Photocatalytic plaster for indoor air purification. 1st National congress of construction mortars, Lisbonn; 2005.

[46] Strini A, Cassese S, Schiavi L. Measurement of benzene, toluene, ethylbenzene and 0 -xylene gas phase photodegradation by titanium dioxide dispersed in cementitious materials using a mixed flow reactor. Appl Catal B Env 2005;61:90-7.

[47] PICADA - Photocatalytic innovative coverings applications for depollution assessment. Innovative facade with de-soiling and de-polluting properties. EC GRD1-2001-00669; 2006.

[48] Maggos T, Plassais A, Bartzis J, Vasilakos C, Moussiopoulos N, Bonafous L. Photocatalytic degradation of NOX in a pilot street configuration using $\mathrm{TiO}_{2-}$ mortar panels. Environ Monit Assess 2008;136:35-44.

[49] Wang S, Ang H, Tade M. Volatile organic compounds in indoor environment and photocatalytic oxidation: state of the art. Environ Int 2007;42:1843-50.

[50] Poon C, Cheung E. NO removal efficiency of photocatalytic paving blocks prepared with recycled materials. Constr Build Mater 2007;21:1746-53.

[51] Guerrini G, Peccati E. Photocatalytic cementitious roads for depollution. In: Baglione P, Cassar I, editors. RILEM International Symposium on photocatalysis environment and construction materials. Italy; 2007; p. 179-86.

[52] Beeldens A. Air purification by road materials: results of the test project. In: Baglione P, Cassar I, editors. RILEM International Symposium on photocatalysis environment and construction materials. Italy; 2007; p. 187-94. 
[53] Auvinen J, Wirtanen L. The influence of photocatalytic interior paints on indoor air quality. Atmos Environ 2008;42:4101-12.

[54] Demeestere K, Dewulf J, De Witte B, Beeldens A, Van Langenhove H. Heterogeneous photocatalytic removal of toluene from air on building materials enriched with $\mathrm{TiO}_{2}$. Build Environ 2008;43:406-14.

[55] Husken G, Hunger M, Brouwers H. Experimental study of photocatalytic concrete products for air purification. Build Environ 2009;44:2463-74.

[56] Chen J, Poon C. Photocatalytic activity of titanium dioxide modified concrete materials - influence of utilizing recycled glass cullets as aggregates. J Environ Manage 2009;90:3436-42.

[57] Kolarik B, Wargocki P, Skorek-Osikowska A, Wisthaler A. The effect of a photocatalytic air purifier on indoor air quality quantified using different measuring methods. Build Environ 2010;45:1434-40.

[58] Ramirez A, Demeestere K, De Belie N, Mantyla T, Levanen E. Titanium dioxide coated cementitious materials for air purifying purposes: preparation, characterization and toluene removal potential. Build Environ 2010;45:832-8.

[59] Ballari M, Hunger M, Husken G, Brouwers H. NOx photocatalytic degradation employing concrete pavement containing titanium dioxide. Appl Catal B Environ 2010;95:245-54.

[60] Hassan M, Dylla H, Mohammad L, Rupnow T. Evaluation of the durability of titanium dioxide photocatalyst coating for concrete pavement. Constr Build Mater 2010;24:1456-61.

[61] Zyska B. Fungi in indoor air in European countries. Mikologia Lekarska 2001;8:127-40

[62] Santucci R, Meunier O, Ott M, Herrmann F, Freyd A, De Blay F. Fungic contamination of residence: 10 years assessment of analyses. Revue Francaise d'Allergologie et d'Immunologie Clinique 2007;47:402-8.

[63] Wiszniewska M, Walusiak-Skorupa J, Gutarowska B, Krakowiak A, Pałczyński C. Is the risk of allergic hypersensitivity to fungi increased by indoor exposure to moulds? Int J Occup Med Environ Health 2009;22:343-54.

[64] Bolashikov Z, Melikov A. Methods for air cleaning and protection of building occupants from airborne pathogens. Build Environ 2009;44:1378-85.

[65] Reboux G, Bellanger A-P, Roussel S, Grenouillet F, Millon L. Moulds in dwellings: health risks and involved species. Revue des Maladies Respiratoires 2010;27:169-79.

[66] Saito T, Iwase J, Horic J, Morioka T. Mode of photocatalytic bactericidal action of powdered semiconductor $\mathrm{TiO}_{2}$ on mutans streptococci. J Photochem Photobio B Bio 1992;14:369-79.

[67] Huang Z, Maness P, Blakem D, Wolfrum E, Smolinski S, Jacoby W. Bactericidal mode of titanium dioxide photocatalysis. J Photochem Photobio A Chem 2000;130:163-70.

[68] Kuhn K, Chaberny I, Massholder K, Stickler M, Benz V, Sootag H, et al. Disinfection of surfaces by photocatalytic oxidation with titanium dioxide and UVA light. Chemosphere 2003;53:71-7.

[69] Cho M, Chung H, Choi W, Yoon J. Linear correlation between inactivation of $E$. coli and $\mathrm{OH}$ radical concentration in $\mathrm{TiO}_{2}$ photocatalytic disinfection. Water Res 2004;38:1069-77.

[70] Vohra A, Goswami D, Deshpande D, Block S. Enhanced photocatalytic disinfection of indoor air. Appl Catal B Environ 2006;65:57-65.

[71] Chen F, Yang X, Wu Q. Antifungal capability of $\mathrm{TiO}_{2}$ coated film on moist wood. Build Environ 2009;44:1088-93.
[72] Calabria J, Vasconcelos W, Daniel D, Chater R, Mcphail D, Boccaccini A. Synthesis of sol-gel titania bactericidal coatings on adobe brick. Constr Build Mater 2010;24:384-9.

[73] Dunnill C, Ziken Z, Pratten J, Wilson M, Morgan D, Parkin I. Enhanced photocatalytic activity under visible light in $\mathrm{N}$-doped $\mathrm{TiO}_{2}$ thin film produced by APCVD preparations using t-butylamine as a nitrogen source and their potential for antibacterial films. J Photochem Photobio A Chem 2009;207:244-53.

[74] Chen F, Yang X, Mak H, Chan D. Photocatalytic oxidation for antimicrobial control in built environment: a brief literature overview. Build Environ 2010;45:1747-54.

[75] Song H, Jiang H, Liu X, Meng G. Efficient degradation of organic pollutant with Wox modified nano $\mathrm{TiO}_{2}$ under visible radiation. J Photochem Phototobio A Chem 2006;181:421-8.

[76] Saepurahman M, Chong F. Preparation and characterization of tungstenloaded titanium dioxide photocatalyst for enhanced dye degradation. J Hazard Mater 2010;176:451-8.

[77] Herrmann J, Duchamp C, Karkmaz M, Hoai B, Lachheb H, Puzenat E, et al. Environmental green chemistry as defined by photocatalysis. J Hazard Mater 2007; 146:624-9.

[78] Grassian V, OShaughnessy P, Adamcakova-Dodd A, Pettibone J, Thorne P. Inhalation exposure study of titanium dioxide nanoparticles with a primary particle size of 2-5 nm. Environ Health Perspec 2007;115:397-402.

[79] Liu A, Sun K, Yang J, Zhao D. Toxicological effects of multi-wall carbon nanotubes in rats. J Nanoparticle Res 2008;10:1303-7.

[80] Poland C, Duffin R, Kinloch I, Maynard A, Seaton WallaceW, Stone A, et al. Carbon nanotubes introduced into the abdominal cavity of mice show asbestos-like pathogenicity in a pilot study. Nat Nanotechnol 2008;3:423-8.

[81] Donaldson K, Poland C. Nanotoxicology: new insights into nanotubes. Nat Nanotechnol 2009;4:708-10.

[82] Pacurari M, Castranova V, Vallyathan V. Single and multi wall carbon nanotubes versus asbestos: are the carbon nanotubes a new health risk to humans. J Toxicol Environ Health 2010;73:378-95.

[83] Hallock M, Greenley P, Diberardinis L, Kallin D. Potential risks of nanomaterials and how to safe handle materials of uncertain toxicity. Division of chemical health and safety of the American chemical society. Elsevier; 2008.

[84] Singh N, Manshian B, Jenkins G, Griffiths S, Williams P, Maffeis T, et al. NanoGenotoxicology: the DNA damaging potential of engineered nanomaterials. Biomaterials 2009;30:3891-914.

[85] Dhawan A, Sharma V, Parmar D. Nanomaterials: a challenge for toxicologists. Nanotoxicology 2009;3:1-9.

[86] Tyshenko M, Krewski D. A risk management framework for the regulation of nanomaterials. Int J Nanotechnol 2008;5:143-60.

[87] Walker N, Bucher J. A 21st century paradigm for evaluating the health hazards of nanoscale materials. Toxicol Sci 2009;110:251-4.

[88] Hirano S. A current overview of health effect research on nanoparticles. Environ Health Preven Med 2009;14:223-5.

[89] Bystrzejewska-Piotrowska G, Golimowski J, Urban P. Nanoparticles: their potential toxicity, waste and environmental management. Waste Manage 2009;29:2587-95. 